\title{
Studying the genetic predisposing factors in the pathogenesis of acne vulgaris
}

\author{
Kornélia Szabó a,b,*, Lajos Kemény a,b \\ a Dermatological Research Group of the Hungarian Academy of Sciences, Szeged, Hungary \\ ${ }^{\mathrm{b}}$ Department of Dermatology and Allergology, University of Szeged, Albert Szent-Györgyi Medical and Pharmaceutical Center, Szeged, Hungary
}

\section{A R T I C L E I N F O}

\section{Article history:}

Received 1 December 2010

Accepted 13 May 2011

Available online 24 May 2011

\section{Keywords:}

Acne vulgaris

Twin studies

Population-based studies

Cross-sectional studies

Molecular genetic studies

\begin{abstract}
A B S T R A C T
Acne is one of the most common dermatologic diseases in the developed regions of the world, affecting a large percentage of the population. Despite the great improvement in the number and quality of studies of the molecular etiology of this disease in the past 3 decades, the detailed molecular pathogenesis and the cause of the large individual variations in severity of skin symptoms remain unknown. The roles of genetic inheritance and special genetic susceptibility and protective factors have been suggested for over 100 years, but their identification and determination started only in the 1990s. To date, only a small number of genetic polymorphisms affecting the expression and/or function of a handful of genes have been investigated. This review surveys the major findings of the classic and molecular genetic studies that have been conducted in this field, draws conclusions, and indicates how the available data help our current understanding of the pathogenesis of this common skin disease.
\end{abstract}

(C) 2011 American Society for Histocompatibility and Immunogenetics. Published by Elsevier Inc. All rights reserved.

\section{Introduction}

Acne is a common and clinically well-characterized skin disease that affects a large percentage of the general population [1]. It is a complex condition in which several factors have been implicated, including hormonal effects, an abnormal keratinocyte function, and microbial components, such as hypercolonization of the skin follicles by the bacterium Propionibacterium acnes [2]. The individual genetic background of those affected has long been suggested to play an important role in the disease pathogenesis, but because of the polygenic character little is known about the exact nature of these factors. All these factors, however, still cannot thoroughly explain the extremely high prevalence rate of this common skin disease that can be observed in Westernized countries [1]; thus, the role of environmental and individual lifestyle factors is becoming more and more appreciated in the pathogenesis of acne.

\section{The early years: twin, family, community-based, and cross-sectional studies}

The idea that hereditable factors play a role in the pathogenesis of acne has a long history. This idea was put forward by 2 prominent dermatologists, Veiel and Wolff, in the second half of the 19th century $[3,4]$.

The first systematic investigations that demonstrated a link between genetic inheritance and various skin diseases (including acne) were performed by a German dermatologist, Hermann Werner Siemens, at the beginning of the 20th century. Siemens was one

\footnotetext{
* Corresponding author.

E-mail address: szabok@mail.derma.szote.u-szeged.hu (K. Szabó).
}

of the first scientists to invent the basic rules of classical twin studies $[4,5]$.

After World War II, as the era of modern biology emerged, studies addressing the inheritance and exact pathogenesis of various diseases became popular. An interesting article by Hecht [3] described his findings on the hereditary trends of acne. He conducted family studies by collecting patients' records using selfmade questionnaires. He established a database on his patients, their relatives, their acne status, and their physical resemblance to one another. His findings led him to conclude that it was possible to predict whether a young child would suffer from acne in adolescence if it was known which relatives the child resembled and whether these relatives were suffering from acne. To substantiate his theses, he presented a detailed picture concerning the inheritance of the physical features and the acne status among his own relatives [3].

Systematic twin studies were also rediscovered and carried out from the end of the 1950s in different countries; they had already proved useful for separation of the contributions of genetic and environmental factors in the pathogenesis of various diseases. The results suggested a strong concordance in the occurrence and severity of acne symptoms in identical twins [6-8] and the accumulation of affected individuals in certain families [9] and they confirmed experimentally that genetic factors play a key role in the pathogenesis of acne vulgaris, the etiology of which was possibly multifactorial $[8,10]$.

Following the discovery of the major pathogenic factors of acne, hormonal equilibrium imbalance and subsequent sebum secretion were suggested to be genetically determined. Comparison of the synthesis of sebum [10] and sebaceous wax esters [11] in identical 
versus nonidentical twins demonstrated the existence of genetic elements controlling sebum secretion.

Acne symptoms are also frequently present on the chest and the back of patients. The twin studies by Evans et al. provided evidence that, in all studied regions affected by acne symptoms and in all studied age groups, the severity of the symptoms was uniformly influenced by genetic factors [12].

Another means of studying various aspects of this common skin disease is to perform population-based and cross-sectional investigations. Many have been reported from various countries, relating to different ethnic groups, and their results are of great value with regard to an understanding of the course of acne, its incidence in certain populations, and other aspects of its inheritance.

Population-based investigations suggest the existence of marked differences among populations with distinct origins. In the developed world, acne vulgaris affects 80 to $90 \%$ of the population [13], whereas in less modernized civilizations, where the population lives a more natural, less industrialized lifestyle, the proportion of affected individuals tends to be much lower. There are even isolated populations where acne is nonexistent, including the inhabitants of the island of Okinawa before World War II [14], the Bantus in South Africa [15,16], the Eskimos [17], isolated South American Indians [18], and Pacific Islanders [19].

Genetic factors may play some role in the complete lack of acne symptoms in these populations, but the strong influence of specific environmental factors cannot be ruled out [19]. These isolated populations tend to have a fairly uniform genetic constitution, although it is quite impossible that they carry genetic factors that would protect them completely from development of the disease. Natural selection is still strong among them because of the lack of antibiotics and other medications, and their immune system is therefore probably more trained to fight various infections. By contrast, the lifelong consumption of low-glycemic food, the resulting enhanced insulin sensitivity, and the low-stress environment possibly lead to a stable homeostasis balance [20-22], whereas a modern lifestyle may tend to push people out of their natural balance to the border of a chronic metabolic disorder $[23,24]$. Thus, the populations in developed countries tend to be overweight, with an increased incidence of cardiac disease, type 2 diabetes, and rheumatoid arthritis [25-27]. Small changes caused in the regulation and/or function of key immune-related genes by genetic polymorphisms might have a greater effect on the immune system of these individuals, and the action of an otherwise commensal bacterium such as $P$ acnes on this off-balance state may be more pronounced. There is as yet no clear-cut experimental evidence that would prove this hypothesis, but certain observations lend support to this idea. Members of these more natural populations are protected from the illnesses of civilization only as long as they live their native lifestyle. As soon as they move to cities and accommodate to more modern conditions, the incidence of chronic diseases (among them acne) increases [19,21,28].

Cross-sectional studies in developed countries involving adolescent schoolchildren in many different locations have revealed that the prevalence of acne progressively increases during the teenage years [18]. The less severe comedonic forms are more prevalent in the general population. The symptoms usually start around the age of 10 to 12 and gradually increase until the age of 16 to 18 $[13,18,29,30]$. At around age 12 the prevalence of the disease is higher in females, but this trend later reverses. In many cases, the disease is self-limited, and the symptoms disappear by the early 20 s, except for a small percentage in whom acne persists even in the adult years. In such individuals, a strong familial predisposition can be detected [31].

The strong involvement of familial inheritance is also noted in patients who display severe inflammatory symptoms [12,13,31,32]. This is especially true for families in which affected individuals are found on both the maternal and the paternal side, although the maternal influence is more important [13].

Although the importance of genetic factors in the pathogenesis of acne has been experimentally proven, there is still no definitive answer as to the exact nature and effects of these factors.

\section{Molecular genetic studies}

The first systematic molecular genetic analyses of a genetic predisposition to acne were performed only in the 1990s [33-35], and since that time only a small number of publications have emerged. Most of the genes studied so far are either key players of innate immune events during lesion formation or have a function in steroid hormone metabolism (Table 1); recently additional polymorphisms and mutations that can be linked to cellular metabolic processes have been published.

\subsection{Polymorphisms of innate immunity-related genes}

Epidermal keratinocytes play an important part in the protection of the host from various external attacks and in preserving the integrity of the organism. They play an active role in the recognition of pathogens and in defense against them [2,36,37].

Pathogen recognition receptors, among them Toll-like receptors (TLRs), have an important function in the initiation of innate immune events in response to various microbes and in the discrimination of microbial ligands. As a result, signal transduction events are initiated in the activated cells, which subsequently cause gene expression changes of many downstream targets, such as cytokines, chemokines, and genes encoding proteins with an antimicrobial function (Fig. 1) [38,39].

\subsubsection{Toll-like receptor gene polymorphisms and acne}

Beginning around puberty, a hormonal imbalance often leads to increased sebum secretion, especially in the facial skin areas $[2,40]$, which initiates the extensive multiplication of $P$ acnes in the follicles $[41,42]$. The pathogen recognition receptors TLR2 and TLR4 are important in the recognition of $P$ acnes in epidermal keratinocytes, and through the initiation of gene expression changes, they regulate downstream innate immune events $[43,44]$.

In the case of the TLR2 gene, an analysis of the Arg753Gln polymorphism by direct sequencing has revealed that the rare $A$ allele is missing from a Central Eastern European study population [45]. The available literature data on the role of this single nucleotide polymorphism (SNP) are controversial and similar investigations performed on other ethnic group by different investigators led to completely different conclusions. The possible explanation is that a highly homologous duplicated segment of exon 3 (harboring the SNP) exists $23 \mathrm{~kb}$ upstream of the TLR2 locus [46]. Extreme care must therefore be taken in studies of the association of the SNP with various diseases, and it must be ensured that the study design is capable of discriminating between the original SNP and its duplicated counterpart. Nevertheless, the in vitro data suggest that if this SNP is truly present in a population, it may be a functional one. The arginine to glycine amino acid change may impair TLR2-mediated immune signaling and the expression of various downstream target genes in response to microbial ligands $[47,48]$. In view of the confirmed functional effect of this SNP, the possibility cannot be ruled out that the $\mathrm{Arg} 753 \mathrm{Gln}$ polymorphism may have a role in the predisposition to various infectious diseases in populations where it is truly present with reasonable frequency.

In the case of TLR4, the Asp299Gly and Thr399Ile changes located in the ligand recognition part of the receptor have been investigated with regard to the genetic predisposition to acne vulgaris by direct sequencing [45]. The results suggested that the SNPs occur simultaneously with relatively low frequency in the previously mentioned Central Eastern European study population, composing a haplotype, and no association was demonstrated between 
Table 1

Genetic polymorphisms studied in the pathogenesis of acne vulgaris

\begin{tabular}{|c|c|c|c|c|c|c|}
\hline & Gene & Polymorphism & rs number & $\begin{array}{l}\text { Type of } \\
\text { polymorphism }\end{array}$ & Location & References \\
\hline \multirow[t]{11}{*}{ Innate immunity genes } & TLR2 & $\begin{array}{l}+2,258(G>A) \\
(\text { Arg753Gly) }\end{array}$ & rs5743708 & SNP & Coding region & Koreck et al. (2006) [45] \\
\hline & TLR4 & $\begin{array}{l}+896(A>G) \\
(\text { Asp299Gly })\end{array}$ & rs4986790 & SNP & Coding region & Koreck et al. (2006) [45] \\
\hline & & $\begin{array}{l}+1,196(\mathrm{C}>\mathrm{T}) \\
\text { (Thr399lle) }\end{array}$ & rs4986791 & SNP & Coding region & Koreck et al. (2006) [45] \\
\hline & MUC1 & 20-aa long tandem repeat & & VNTR & Coding region & Ando et al. (1998) [2] \\
\hline & TNFA & $-238(G>A)$ & rs361525 & SNP & Promoter & $\begin{array}{l}\text { Sobjanek et al. (2009) [62] } \\
\text { Szabó et al. (2010) [61] }\end{array}$ \\
\hline & & $-308(G>A)$ & rs1800629 & SNP & Promoter & $\begin{array}{l}\text { Baz et al. (2008) [60] } \\
\text { Sobjanek et al. (2009) [62] } \\
\text { Szabo et al. (2010) [61] }\end{array}$ \\
\hline & & $-857(C>T)$ & rs1799724 & SNP & Promoter & Szabó et al. (2010) [61] \\
\hline & & $-863(C>A)$ & rs1800630 & SNP & Promoter & Szabó et al. (2010) [61] \\
\hline & & $-1031(\mathrm{~T}>\mathrm{C})$ & rs1799964 & SNP & Promoter & Szabó et al. (2010) [61] \\
\hline & IL-1A & $+4,845(\mathrm{G}>\mathrm{T})$ & rs17561 & SNP & Coding region & Szabó et al. (2010) [70] \\
\hline & IL1RN & 86-bp-long tandem repeat & & VNTR & Intron & Szabó et al. (2010) [61] \\
\hline \multirow[t]{5}{*}{$\begin{array}{l}\text { Genes affecting steroid hormone } \\
\text { metabolism }\end{array}$} & $\mathrm{AR}$ & CAG and GGN repeat polymorphism & & VNTR & Promoter & $\begin{array}{l}\text { Sawaya and Shalita (1999) [35] } \\
\text { Yang et al. (2009) [81] } \\
\text { Pang et al. (2008) [82] }\end{array}$ \\
\hline & CYP1A1 & $\begin{array}{l}+4,889(A>G) \\
\text { (Ile462Val) }\end{array}$ & rs1048943 & SNP & Coding region & Paraskevaidis et al. (1998) [33] \\
\hline & & $+6,235(\mathrm{~T}>\mathrm{C})$ & rs4646903 & SNP & 3' UTR & Paraskevaidis et al. (1998) [33] \\
\hline & CYP17 & $-34(\mathrm{~T}>\mathrm{C})$ & rs743572 & SNP & Promoter & He et al. (2006) [92] \\
\hline & Gene & Mutation & & Location & & References \\
\hline Other genes & FGFR2 & S252W, P253R & & Coding region & & $\begin{array}{l}\text { Munro and Wilkie (1998) [95] } \\
\text { Melnik et al. (2008) [96] }\end{array}$ \\
\hline
\end{tabular}

Competing interests. The authors state no conflict of interest.

the carriers of the polymorphisms and acne. The close linkage of these 2 SNPs in other populations of Caucasian origin was likewise reported by others [49].

Most in vitro functional studies suggest that the LPS-induced cytokine response of the Asp299Gly/Thr399Ile haplotype does not differ from that of the wild-type cytokine response. There is 1 report, however, of an increased tumor necrosis factor- $\alpha$ (TNF- $\alpha$ ) cytokine response of the Asp299Gly/wild-type haplotype, which is reported almost exclusively in Africa [50].

\subsubsection{Polymorphisms of genes with anti-inflammatory properties}

Mucins are high-molecular-weight glycoproteins expressed by different cell types of epithelial origin. They can be secreted or membrane tethered [51]. MUC1 (also known as PEM), a cell surface mucin, has been demonstrated to be involved in various processes during pathogen infection, including the binding of the attacking pathogens. The mucins initiate active protection via the regulation

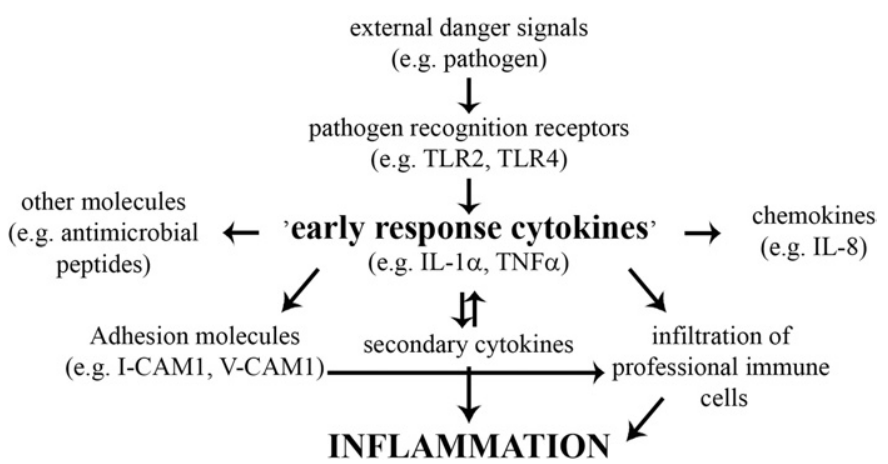

Fig. 1. Epidermal keratinocytes can recognize external danger signals via various pathogen recognition receptors. Their activation initiates innate immune events, orchestrated by early response cytokines, including TNF- $\alpha$ and IL- $1 \alpha$. As a result, the expression of various downstream target genes increases. Extensive activation of these signaling cascades can lead to uncontrolled inflammation. of cellular signaling and transcription, mainly by interfering with the nuclear factor $\kappa \mathrm{B}(\mathrm{NF}-\kappa \mathrm{B})$ signal transduction pathway, thereby exhibiting potent anti-inflammatory properties during the pathogen challenge of epithelial cells [37].

Variable number of tandem repeat polymorphisms (VNTR) are present in the heavily glycosylated extracellular domain of MUC1containing repeats of a 20-amino-acid sequence [52]. MUC1 alleles are divided into 2 arbitrary size classes based on the number of tandem repeats. So far, there has been only one study investigating the effects of this VNTR polymorphism in acne vulgaris in a Japanese population; it revealed a significant difference in the size distribution between the controls and severe acne patients, with a higher percentage of long alleles in the latter group. No difference was detected between the controls and the patients with mild acne symptoms [53].

No in vitro data are available that describe the difference between the short and long alleles in the pathogenesis of acne. Long alleles may be more efficient in pathogen binding, possibly resulting in enhanced bacterial colonization and susceptibility to various infectious diseases in the carriers [54].

\subsubsection{Polymorphisms of "early response" cytokines}

Upon the activation of pattern recognition receptors, a rapid signaling cascade is initiated in the cytoplasm of the keratinocytes, leading to the increased expression of downstream target genes: these include genes encoding the cytokines TNF- $\alpha$ and interleukin- $1 \alpha($ IL- $1 \alpha)[55,56]$.

3.1.3.1. The role of TNF- $\alpha$ in the predisposition to acne. The TNFA gene encoding the TNF- $\alpha$ cytokine is located on the short arm of chromosome 6 (6p21.3) in the major histocompatibility class III region, where a high degree of genetic polymorphism is a characteristic feature. Different types of polymorphisms exist in the TNFA promoter, including SNPs and microsatellites, whereas the coding region is highly conserved [57]. 
The cytokine TNF- $\alpha$ is a key molecule in various biologic processes, and its misregulation can have deleterious effects for the host organism. The SNPs in the promoter region can play a role in the allele-specific regulation of gene expression and are often reported to act as protective or disease-predisposing factors in the development of inflammatory and infectious diseases and certain types of cancers $[58,59]$.

To date, there have been 3 reports of the role of TNFA promoter SNPs in the pathogenesis of acne vulgaris. The TNFA -308G $>$ A polymorphism was common in all of them, but the conclusions are different. The report by Baz et al. [60] demonstrates a strong association between the minor A allele of this SNP and acne vulgaris in a Turkish population, but neither gender-specific differences nor any association between the severity of acne and the various genotypes were detected. In our studies on the Central European population, no association was detected in the dataset overall, but a significant association was discovered between the minor A allele and acne in female patients. A positive correlation was also detected between the severity of inflammatory symptoms and the frequency of the A allele in the females of this population [61]. In the third report, Sobjanek et al. reported similar results on a Polish population, with no association between their dataset overall and acne. They did not investigate gender-specific differences [62]. The reason for these differences is currently not clear, but it is interesting that the frequency of the A allele exhibits large geographic difference from east to west $[60,61]$. The results might be explained by differences in the linkage groups associated with the TNF- $\alpha-308$ SNP in the geographically distant populations studied.

The Polish and our own studies also investigated the role of the TNFA -238G > A SNP and acne; no association was reported in either population, suggesting that it might not play a role in the pathogenesis of acne [61,62].

Three other TNFA polymorphisms have been studied in the above-mentioned Central Eastern European population. No correlation of the TNFA $-1031 \mathrm{X}>\mathrm{Y}$ and the $-863 \mathrm{X}>\mathrm{Y}$ SNP-s and acne was detected. In the case of the $-857 \mathrm{C}>\mathrm{T}$ SNP, the frequent $\mathrm{C}$ allele exhibited a positive association with acne, whereas the minor $\mathrm{T}$ allele seemed to have a protective effect [61]. The current model suggests that in the presence of the minor $\mathrm{T}$ allele, a novel transcription factor binding site (OCT-1) is generated at the promoter region of the TNFA gene, immediately next to a preexisting NF- $\kappa$ B binding site. As a result, an altered regulation of the gene might be generated in response to various stimuli, which involves the activation of NF- $\kappa \mathrm{B}$ [63]. The protective nature of the $-857 \mathrm{~T}$ allele has also been suggested by reports on the pathogenesis of other chronic inflammatory diseases, suggesting the general importance of this SNP in the regulation of TNFA gene expression $[63,64]$.

3.1.3.2. The role of genetic polymorphisms of IL-1 $\alpha$ family members in the pathogenesis of acne. The role of IL- $1 \alpha$ in the pathogenesis of acne has been investigated for some time [65-67]. This multifunctional pleiotropic cytokine affects different cell types and is important in linking the innate and adaptive immune responses. It plays a central part in cutaneous inflammatory reactions, is highly inflammatory, and exerts deleterious effects if its regulation, production, or function is disturbed. In the pathogenesis of acne, elevated IL-1 expression can be detected in every step of lesion formation, and external treatment with IL- $1 \alpha$ protein alone causes comedonal features (e.g., hyperproliferation and abnormal differentiation in isolated pilosebaceous units in vitro) $[68,69]$.

A case-control study revealed a positive association between the rare $\mathrm{T}$ allele of the $+4,845(\mathrm{G}>\mathrm{T}) \mathrm{SNP}$ and acne, as well as a correlation between the severity of acne symptoms and the frequency of the minor allele-containing genotypes [70].

IL- $1 \alpha$ protein is synthesized as pre-IL- $1 \alpha$ and processed into the mature form by the enzymatic cut between amino acids 117 and
118 [71]. Both isoforms are biologically active, with different subcellular localizations and hence biologic functions [72,73]. PreIL- $1 \alpha$ has a predominantly nuclear localization, whereas the mature protein exhibits a cytoplasmic localization and can be secreted in response to the appropriate signals [71].

The SNP at position $+4,845$ of the gene causes an alanine to serine substitution close to the proteolytic cleavage site and might result in enhanced cleavage when the rare $T$ allele is present $[73,74]$. This leads to different ratios of nuclear versus secreted IL- $1 \alpha$ isoforms, which can have a potent effect on the regulation of epidermal homeostasis; carriers of the rare $\mathrm{T}$ allele may therefore be at higher risk of more severe acne symptoms (Fig. 2) [70].

We have also investigated the role of the VNTR polymorphism of the IL1RN gene, a naturally existing IL-1 receptor antagonist. Although it has been demonstrated in many cases that various alleles of this polymorphism often act as predisposing factors in the development of chronic inflammatory diseases, no association with acne was reported [70].

\subsection{Polymorphisms of genes playing a role in the steroid hormone metabolism}

The pilosebaceous unit, an endocrine organ, is an important source of localized hormone production, but also a target of various hormones synthesized elsewhere in the human body [75].

\subsubsection{The role of androgen biosynthesis genes in the pathogenesis of acne}

Androgens have long been known to play a key role in the development of acne [76,77], seborrhoea [75], hirsutism, and androgenic alopecia [78].

3.2.1.1. Androgen receptor VNTR polymorphism and the predisposition to acne. Androgens bind to an intracellular receptor (androgen receptor $[A R])$. Upon binding, the activated AR receptor-ligand complex translocates to the nucleus and moderate gene expression changes. The AR gene is located on the X chromosome (XQ11-12) and is highly polymorphic. The N-terminal domain of the AR receptor contains a polyglutamine stretch, encoded by polymorphic CAG repeats of variable length, and also a polyglycine stretch encoded by a GGN repeat. The variations in repeat lengths in case of both types of repeats have been demonstrated to be associated with subtle modulations of AR gene expression, resulting in the modified transcriptional activity of various downstream targets. An inverse correlation seems to exist between the CAG repeat length and androgen gene expression over the range of normal alleles, with the shorter alleles exhibiting the greatest activity [79]. As a consequence, carriers of shorter alleles are prone to develop various androgen-dependent conditions, such as prostate cancer [80] and benign prostate hyperplasia [51]. The effect of the GGN repeat is less clear, but there are also reports suggesting its effect in disease pathogenesis.

Considering all available data, it is tempting to speculate that the CAG repeat polymorphism of the AR gene should play a role in the predisposition to acne. However, the study by Sawaya and Shalita did not indicate a statistically significant difference when the average CAG repeat length was compared in male and female controls and acne patients, although more male patients carried alleles with shorter repeat length $(<20)$ [35].

Yang et al. [81] reported a statistically significant difference between controls and male acne patients in a Chinese Han population, but no such difference was detected in females. In vitro results suggest that acne patients carrying fewer CAG repeats may exhibit a higher AR mRNA and protein expression, leading to higher sensitivity to androgens than in control individuals [79].

Similar results were published by Pang et al. [82] in a study of males from northeast China, who reported that patients carrying 


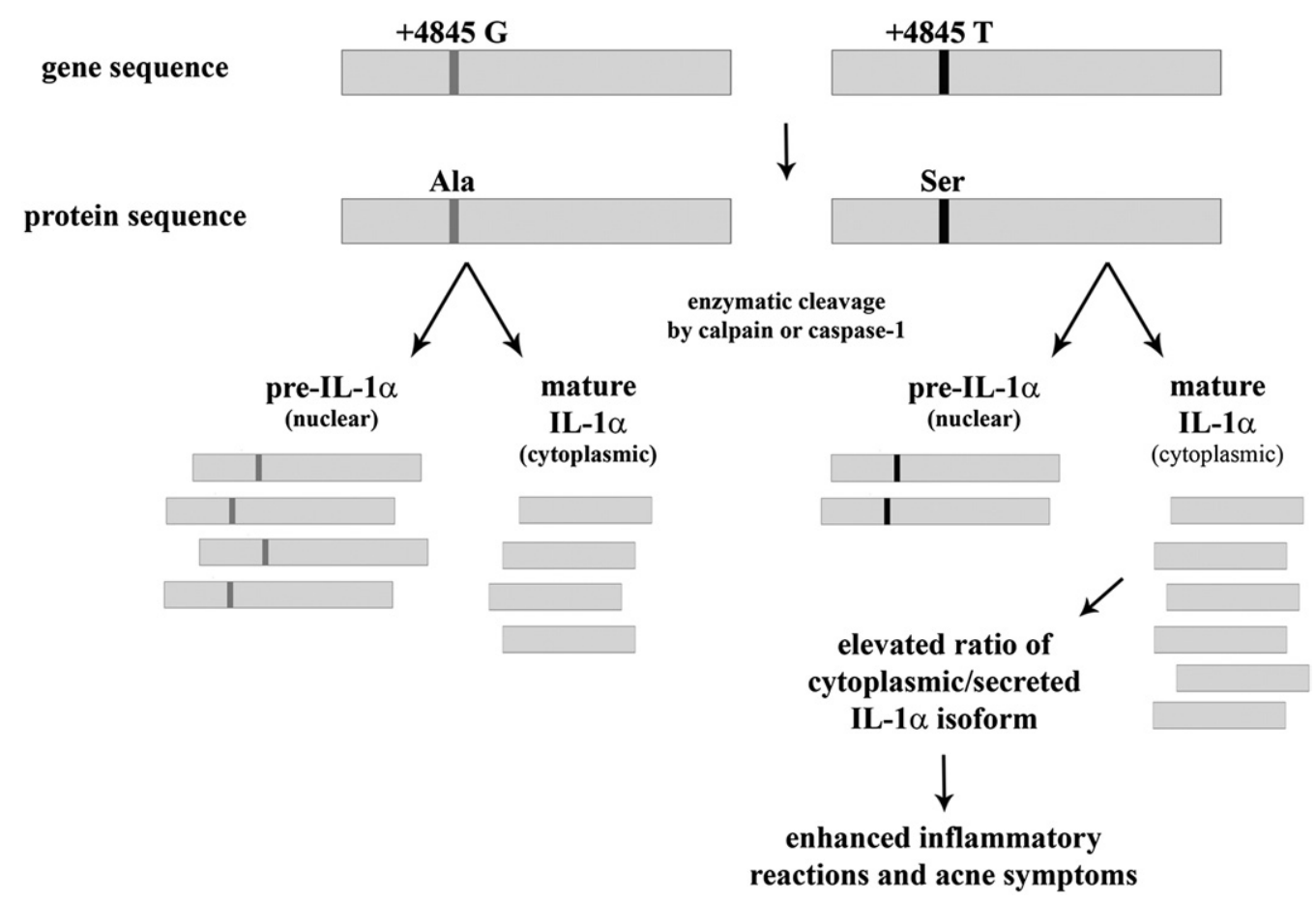

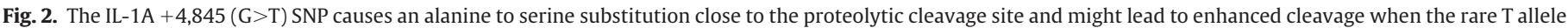

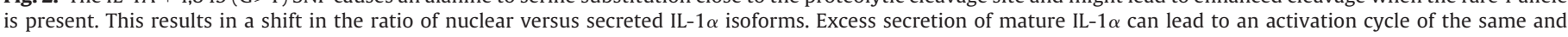
surrounding cells in an autocrine and paracrine manner, leading to uncontrolled inflammatory reactions.

fewer than 23 repeat have a higher chance to suffer from acne. However, in contrast with the results of Yang et al. [81], they also reported an association in the studied female population. Similar to males, females carrying fewer than 24 repeats exhibited increased acne risk [82]. The number of GNN repeats alone was not associated with acne, although a trend for shorter repeat numbers was noted in male patients. Combined analysis of both repeats suggested that specific combinations with fewer than 23 repeats in either position occur more frequently among male acne patients.

The reason for the differences between the Chinese and the American studies is not known. Yang et al. [82] argue that it might reflect differences in the 2 ethnic groups. Alternatively, Sawaya and Shalita [35] studied only a limited number of controls and patients, and each group was a mixture of individuals with various ethnic backgrounds (Hispanic, African, and Caucasian). As populationrelated differences can be observed in the average CAG repeat length of the AR gene, this tends to make interpretation of their result difficult.

3.2.1.2. Genetic polymorphisms of cytochrome P450 family genes and acne. The enzymes encoded by various genes of the cytochrome P450 family are involved in the metabolism of various molecules and chemicals, including lipids, steroid hormones, and external drug molecules.

One of the first investigations of the association of various genetic elements and acne vulgaris was published by Paraskevaidis et al. [33], who studied a member of this family, CYP1A1. CYP1A1 is a key enzyme involved in the metabolism of endogenous retinoids and vitamin A [83], and its natural metabolites have been demonstrated to be morphogenic for the sebaceous glands $[84,85]$. Two polymorphisms were studied: 1 in the 7 th exon $(4889 A>G)$, and another in the $3^{\prime}$ untranslated region [6235( $\left.\left.\mathrm{T}>\mathrm{C}\right)\right]$. Although the SNP in the coding region seems to give rise to increased enzymatic activity [86,87], no difference was detected in the distribution of various genotypes and alleles in the controls and the acne patients, suggesting that it does not play a role in the predisposition to acne
[33]. Carriers of the rare $C$ allele of the $6235(T>C)$ SNP were overrepresented in the patient group, but the difference was not statistically significant in this case either [33].

The CYP17 gene is one of the key enzymes involved in the androgen biosynthesis mediating steroid $17 \alpha$-hydroxilase and 17,20 -lyase bioactivities [88]. The role of the $-34 \mathrm{~T}>\mathrm{C}$ promoter polymorphism has been investigated in various types of endocrinopathies and cancers too, and positive associations have been reported between this SNP and premature baldness, polycystic ovary syndrome [89], and breast cancer [90]. In prostate cancer various findings have been reported [91], and the association with this disease has therefore not been proven beyond doubt.

Currently, the only known study of the role of the CYP17 -4T $>C$ polymorphism in acne vulgaris in a Chinese population reported an association between the carriage of the rare C allele in a homozygote form and severe cases of acne vulgaris in male patients [92]. It is suggested that the polymorphism may affect the regulation of the CYP17 gene by creating a novel SP1 promoter-binding site [89], although in vitro EMSA experiments have so far not furnished physical evidence of the SP1 binding of this putative "novel" site [93]. However, the fact that several studies have indicated an association between the SNP and different endocrinopathies suggests that the role of this polymorphism is currently controversial, and establishment of its exact molecular function requires further investigations.

\subsection{The role of FGFR2 mutations in the pathogenesis of acne}

Fibroblast growth factor receptor 2 (FGFR2) and the signaling events that are generated upon receptor activation play an important role in the pathogenesis of acne. Naturally occurring gain-offunction germline mutations of the FGFR2 gene (S252W, P253R) have been demonstrated to cause Apert syndrome, an autosomal dominant congenital disorder characterized by malformations of the skull, face, hands, and feet, together with skin manifestations, including oily skin, and an unusually distributed moderate to se- 
vere acne with the lesions extending to the forearms [94]. The skin symptoms are the direct consequences of the above-described mutations [95,96]. Munroe and Wilkie [95] and later Melnik [96] described 2 cases where the same rare somatic mutation was detected as in many cases of Apert syndrome patients. Both reports describe patients exhibiting unilateral, atypically distributed acne that followed the Blaschko lines, but no other signs (e.g., cranial malformations) characteristic of Apert syndrome were apparent. They could demonstrate the presence of the somatic FGFR2 mutation (S252W) in both cases only from the affected skin areas, whereas other samples proved to be wild type.

The exact role of FGFR2 in the pathogenesis of acne is currently not clear, but downstream activation of the MAPK and PI3K/Akt pathways might have a role.

\section{Discussion}

Long-known classic pathogenic factors playing an important role in acne pathogenesis include hormonal effects, the consequence of abnormal keratinocyte function, hypercolonization by $P$ acnes bacterium, and genetics. Earlier sporadic reports also suggested the effect of various environmental and lifestyle factors, but their true importance was under scientific debate. In the past few years, our view of acne and its pathogenesis has changed. The effect of hormones, the bacterium, and the abnormal keratinocyte function is still unquestionable [2], but new data strengthen the role of the environmental effects, suggesting that the pathogenesis of this common skin disease is even more complex than thought a couple of years ago [23,24,97].

Genetic studies have over a 100-year history. Classic twin [6-8,10,11] and population-based studies [13-19] provided unambiguous evidence concerning the role of inherited factors in the pathogenesis of acne. Cross-sectional and population-based investigations have yielded clear evidence on the exact course of the disease and the differences that can be observed in different populations. They also suggest that acne may be linked to the homeostasis imbalance caused by our modern lifestyle [19]. All these effects can lead to an enhanced sensitivity to various external stimuli, which enhances the proneness to the development of chronic inflammatory diseases $[24,25]$. In this state, small changes in the levels of various proinflammatory cytokines or in the metabolism of hormones and other bioactive small molecules will lead to chronic inflammatory diseases. Such small changes can arise from genetic polymorphisms that affect the expression and/or function of key genes.

So far, the roles of only a handful of genes have been studied as genetic predisposing or susceptibility factors in the pathogenesis of acne. They affect 2 major cellular processes: regulation of the steroid hormone metabolism or the innate immune function of epidermal keratinocytes. The effects of the hormonal system on acne were suggested long ago, but the contribution of an improper function of innate immunity, and hence the exact part played by $P$ acnes in these events, is more controversial. We believe that the currently available data clearly indicate that the colonization of $P$ acnes at around the age of puberty and the subsequently initiated and somehow skewed innate immune events are important factors in the development of acne.

More and more data describe the effect of a Westernized lifestyle on health and disease state of the population of developed countries. Studies comparing various populations living natural versus industrialized lifestyles suggest that the impact of constant stress, decreased physical activity, and imbalanced diet is enormous in the latter types of populations. As a result, the incidence of illnesses such as type 2 diabetes, rheumatoid arthritis, and heart diseases is rapidly increasing $[24,25,97]$. The question is whether there is also a correlation among these lifestyle factors and the high prevalence of acne in Westernized countries. If a correlation exists, then we need to change how we think about acne and examine new ways to study this skin disease. Consumption of high-glycemic and hyperinsulinemic food leads to increased insulin-like growth factor 1 (IGF-1) levels and subsequently initiates endocrine responses and androgen synthesis [97]. As a consequence, genetic and molecular studies investigating the role of the IGF-1, insulin-like growth factor receptor 1 , insulin-like growth factor binding protein 3 , and other elements of this cascade, including the nuclear receptors (LXR, RXR, RAR) and downstream targets (e.g., the FoxO1 transcription factor), should be initiated $[23,97,98]$.

Nutritional imbalance and metabolic disturbances early in life may later have a persistent effect on an adult's health that may even be transmitted to subsequent generations by the induction of epigenetic changes, as demonstrated in the context of cardiovascular diseases [99].

Taken together, the small number of molecular genetic studies performed to date to discover the exact molecular pathogenesis of this common skin disease is surprising. The studies only target a handful of genes and only carefully selected genetic polymorphisms. High-throughput global genomic approaches could greatly facilitate these types of investigations.

We believe that carefully planned molecular genetic studies will not only continue to enhance our current understanding of this very common skin disease, but also shed light on the various physiologic and pathologic processes involving epidermal keratinocytes.

\section{Acknowledgments}

The authors thank Dr Márta Széll for her critical reading of the manuscript and her helpful remarks. We also thank the reviewers for their excellent suggestions and comments. KSz was funded by OTKA Grant PD 73485. This work was also funded by TÁMOP-4.2.1/ B-09/1/KONV-2010-0005, Creating the Center of Excellence at the University of Szeged, supported by the European Union and cofinanced by the European Regional Development Fund.

\section{Appendix. Supplementary data}

Supplementary data associated with this article can be found, in the online version, at doi:10.1016/j.humimm.2011.05.012.

\section{References}

[1] Zouboulis CC, Eady A, Philpott M, Goldsmith LA, Orfanos C, Cunliffe WC, et al What is the pathogenesis of acne? Exp Dermatol 2005;14:143-52.

[2] Koreck A, Pivarcsi A, Dobozy A, Kemény L. The role of innate immunity in the pathogenesis of acne. Dermatology (Basel) 2003;206:96-105.

[3] Hecht H. Hereditary trends in acne vulgaris. Prevention of acne. Dermatologica 1960;121:297-307.

[4] Siemens HW. Die Vererbung in der Aetiologie der Hautkrankheiten. In: Jadassohn J, editor. Handbuch der Haut-und Geschlechtskrankheiten, Berlin: J Springer; 1929.

[5] Siemens HW. Die Zwillingspathologie, Ihre Bedeutung, Ihre Methodik, Ihre Bisherigen Ergebnisse, Berlin: J. Springer; 1924.

[6] Niermann H. Report on 230 twins with skin diseases. Z Mensch Vererb Konstitutionsl 1958;34:483-7.

[7] Friedman GD. Twin studies of disease heritability based on medical records: application to acne vulgaris. Acta Genet Med Gemellol [Roma] 1984; 33:487-95.

[8] Bataille V, Snieder H, MacGregor AJ, Sasieni P, Spector TD. The influence of genetics and environmental factors in the pathogenesis of acne: a twin study of acne in women. J Invest Dermatol 2002;119:1317-22.

[9] Gloor M, Hübscher M, Friederich HC. [External treatment of acne vulgaris using tetracycline and estrogen]. Hautarzt 1974;25:391-4.

[10] Walton S, Wyatt EH, Cunliffe WJ. Genetic control of sebum excretion and acne-a twin study. Br J Dermatol 1988;118:393-6.

[11] Stewart ME, McDonnell MW, Downing DT. Possible genetic control of the proportions of branched-chain fatty acids in human sebaceous wax esters. J Invest Dermatol 1986;86:706-8.

[12] Evans DM, Kirk KM, Nyholt DR, Novac C, Martin NG. Teenage acne is influenced by genetic factors. Br J Dermatol 2005;152:579-81.

[13] Ghodsi SZ, Orawa H, Zouboulis CC. Prevalence, severity, and severity risk factors of acne in high school pupils: a community-based study. J Invest Dermatol 2009;129:2136-41.

[14] Steiner PE. Necropsies on Okinawans: anatomic and pathologic observations. Arch Pathol 2010;42:359-80. 
[15] Findlay GH. The age incidence of common skin diseases in the white population of the Transvaal. Br J Dermatol 1967;79:538-42.

[16] Park RG. The age distribution of common skin disorders in the Bantu of Pretoria, Transvaal. Br J Dermatol 1968;80:758 - 61.

[17] Schaefer O. When the Eskimo comes to town. Nutr Today 2010;6:8-16.

[18] Freyre EA, Rebaza RM, Sami DA, Lozada CP. The prevalence of facial acne in Peruvian adolescents and its relation to their ethnicity. J Adolesc Health 1998; 22:480-4.

[19] Cordain L, Lindeberg S, Hurtado M, Hill K, Eaton SB, Brand-Miller J. Acne vulgaris: a disease of Western civilization. Arch Dermatol 2002:138:1584-90.

[20] Merimee TJ, Rimoin DL, Cavalli-Sforza LL. Metabolic studies in the African Pygmy. J Clin Invest 1972;51:395-401.

[21] O'Dea K. Marked improvement in carbohydrate and lipid metabolism in diabetic Australian aborigines after temporary reversion to traditional lifestyle. Diabetes 1984;33:596-603.

[22] Spielman RS, Fajans SS, Neel JV, Pek S, Floyd JC, Oliver WJ. Glucose tolerance in two unacculturated Indian tribes of Brazil. Diabetologia 1982;23:90-3.

[23] Melnik BC, Schmitz G. Role of insulin, insulin-like growth factor-1, hyperglycaemic food and milk consumption in the pathogenesis of acne vulgaris. Exp Dermatol 2009; 18:833-41.

[24] Melnik B. Milk consumption: aggravating factor of acne and promoter of chronic diseases of Western societies. J Dtsch Dermatol Ges 2009;7:364-70.

[25] Duvnjak L, Duvnjak M. The metabolic syndrome-an ongoing story. J Physiol Pharmacol 2009;60; suppl 7:19-24.

[26] Choi K, Kim YB. Molecular mechanism of insulin resistance in obesity and type 2 diabetes. Korean J Intern Med 2010;25:119-29.

[27] Gonzalez-Gay MA, Gonzalez-Juanatey C, Vazquez-Rodriguez TR, Miranda-Filloy JA, Llorca J. Insulin resistance in rheumatoid arthritis: the impact of the anti-TNFalpha therapy. Ann N Y Acad Sci 2010;1193:153-9.

[28] Ebbesson SO, Schraer CD, Risica PM, Adler AI, Ebbesson L, Mayer AM, et al. Diabetes and impaired glucose tolerance in three Alaskan Eskimo populations. The Alaska-Siberia Project. Diabetes Care 1998;21:563-9.

[29] Lucky AW, Biro FM, Huster GA, Morrison JA, Elder N. Acne vulgaris in early adolescent boys. Correlations with pubertal maturation and age. Arch Dermatol 1991;127:210-6.

[30] Lucky AW, Biro FM, Huster GA, Leach AD, Morrison JA, Ratterman J. Acne vulgaris in premenarchal girls. An early sign of puberty associated with rising levels of dehydroepiandrosterone. Arch Dermatol 1994;130:308-14.

[31] Goulden V, McGeown CH, Cunliffe WJ. The familial risk of adult acne: a comparison between first-degree relatives of affected and unaffected individuals. $\mathrm{Br} J$ Dermatol 1999;141:297-300.

[32] Dreno B, Poli F. Epidemiology of acne. Dermatology (Basel) 2003;206:7-10.

[33] Paraskevaidis A, Drakoulis N, Roots I, Orfanos CE, Zouboulis CC. Polymorphisms in the human cytochrome P-450 1A1 gene (CYP1A1) as a factor for developing acne. Dermatology (Basel) 1998;196:171-5.

[34] Ostlere LS, Rumsby G, Holownia P, Jacobs HS, Rustin MH, Honour JW. Carrier status for steroid 21-hydroxylase deficiency is only one factor in the variable phenotype of acne. Clin Endocrinol (Oxf) 1998;48:209-15.

[35] Sawaya ME, Shalita AR. Androgen receptor polymorphisms (CAG repeat lengths) in androgenetic alopecia, hirsutism, and acne. J Cutan Med Surg 1998;3:9-15.

[36] Pivarcsi A, Kemény L, Dobozy A. Innate immune functions of the keratinocytes. A review. Acta Microbiol Immunol Hung 2004;51:303-10.

[37] Kim KC, Lillehoj EP. MUC1 mucin: a peacemaker in the lung. Am J Respir Cell Mol Biol 2008;39:644-7.

[38] Medzhitov R. Toll-like receptors and innate immunity. Nat Rev Immunol 2001; $1: 135-45$.

[39] Kumagai Y, Akira S. Identification and functions of pattern-recognition receptors. J Allergy Clin Immunol 2010;125:985-92.

[40] Pochi PE, Strauss JS. Sebaceous gland response in man to the administration of testosterone, delta-4-androstenedione, and dehydroisoandrosterone. J Invest Dermatol 1969;52:32-6.

[41] Unna PG. The Histopathology of the Diseases of the Skin, Edinburgh: Clay, W. F.; 1896.

[42] Dessinioti C, Katsambas AD. The role of Propionibacterium acnes in acne pathogenesis: facts and controversies. Clin Dermatol 2010;28:2-7.

[43] Kim J. Review of the innate immune response in acne vulgaris: activation of Toll-like receptor 2 in acne triggers inflammatory cytokine responses. Dermatology (Basel) 2005;211:193-8.

[44] Nagy I, Pivarcsi A, Koreck A, Széll M, Urbán E, Kemény L. Distinct strains of Propionibacterium acnes induce selective human beta-defensin-2 and interleukin-8 expression in human keratinocytes through Toll-like receptors. J Invest Dermatol 2005;124:931-8.

[45] Koreck A, Kis K, Szegedi K, Paunescu V, Cioaca R, Olariu R, et al. TLR2 and TLR4 polymorphisms are not associated with acne vulgaris. Dermatology (Basel) 2006;213:267-9.

[46] Malhotra D, Relhan V, Reddy BS, Bamezai R. TLR2 Arg677Trp polymorphism in leprosy: revisited. Hum Genet 2005;116:413-5

[47] Brown RA, Gralewski JH, Razonable RR. The R753Q polymorphism abrogates Toll-like receptor 2 signaling in response to human cytomegalovirus. Clin Infect Dis 2009;49:e96-9.

[48] Brown RA, Gralewski JH, Eid AJ, Knoll BM, Finberg RW, Razonable RR. R753Q single-nucleotide polymorphism impairs Toll-like receptor 2 recognition of hepatitis C virus core and nonstructural 3 proteins. Transplantation 2010;89: 811-5.
[49] Ferwerda B, McCall MB, Verheijen K, Kullberg BJ, van der Ven AJ, van der Meer $\mathrm{JW}$, et al. Functional consequences of Toll-like receptor 4 polymorphisms. Mol Med 2008; $14: 346-52$.

[50] Ferwerda B, McCall MB, Alonso S, Giamarellos-Bourboulis EJ, Mouktaroudi M, Izagirre $\mathrm{N}$, et al. TLR4 polymorphisms, infectious diseases, and evolutionary pressure during migration of modern humans. Proc Natl Acad Sci U S A 2007; 104:16645-50.

[51] Theodoropoulos G, Carraway KL. Molecular signaling in the regulation of mucins. J Cell Biochem 2007;102:1103-16.

[52] Hanisch FG, Müller S. MUC1: the polymorphic appearance of a human mucin Glycobiology 2000;10:439-49.

[53] Ando I, Kukita A, Soma G, Hino H. A large number of tandem repeats in the polymorphic epithelial mucin gene is associated with severe acne. J Dermatol 1998;25:150-2.

[54] Costa NR, Mendes N, Marcos NT, Reis CA, Caffrey T, Hollingsworth MA, et al Relevance of MUC1 mucin variable number of tandem repeats polymorphism in $H$ pylori adhesion to gastric epithelial cells. World J Gastroenterol 2008;14: 1411-4.

[55] Pomerantz JL, Baltimore D. Two pathways to NF-kappaB. Mol Cell 2002;10: 693-5.

[56] Takeuchi O, Hoshino K, Kawai T, Sanjo H, Takada H, Ogawa T, et al. Differentia roles of TLR2 and TLR4 in recognition of gram-negative and gram-positive bacterial cell wall components. Immunity 1999;11:443-51.

[57] Waldron-Lynch F, Adams C, Shanahan F, Molloy MG, O'Gara F. Genetic analysis of the $3^{\prime}$ untranslated region of the tumour necrosis factor shows a highly conserved region in rheumatoid arthritis affected and unaffected subjects. J Med Genet 1999;36:214-6.

[58] Knight JC. Regulatory polymorphisms underlying complex disease traits. J Mol Med 2005;83:97-109.

[59] Smith AJ, Humphries SE. Cytokine and cytokine receptor gene polymorphisms and their functionality. Cytokine Growth Factor Rev 2009;20:43-59.

[60] Baz K, Emin EM, Yazici AC, Soylemez F, Guvenc U, Tasdelen B, et al. Association between tumor necrosis factor-alpha gene promoter polymorphism at position -308 and acne in Turkish patients. Arch Dermatol Res 2008;300:371-6.

[61] Szabó K, Tax G, Teodorescu-Brinzeu D, Koreck A, Kemény L. TNF $\alpha$ gene polymorphisms in the pathogenesis of acne vulgaris. Arch Dermatol Res 2011;303: $19-27$.

[62] Sobjanek M, Zabłotna M, Nedoszytko B, Sokołowska-Wojdyło M, Włodarkiewicz A. Lack of association between the promoter polymorphisms at positions -238 and -308 of the tumour necrosis factor alpha gene and acne vulgaris in Polish patients. J Eur Acad Dermatol Venereol 2009;23:331-2.

[63] van Heel DA, Udalova IA, De Silva AP, McGovern DP, Kinouchi Y, Hull J, et al. Inflammatory bowel disease is associated with a TNF polymorphism that affects an interaction between the OCT1 and NF(-kappa)B transcription factors. Hum Mol Genet 2002:11:1281-9.

[64] Ferguson LR, Huebner C, Petermann I, Gearry RB, Barclay ML, Demmers P, et al. Single nucleotide polymorphism in the tumor necrosis factor-alpha gene affects inflammatory bowel diseases risk. World J Gastroenterol 2008;14: 4652-61.

[65] Guy R, Green MR, Kealey T. Modeling acne in vitro. J Invest Dermatol 1996;106: $176-82$.

[66] Aldana OL, Holland DB, Cunliffe WJ. Variation in pilosebaceous duct keratinocyte proliferation in acne patients. Dermatology (Basel) 1998;196:98-9.

[67] Guy R, Kealey T. The effects of inflammatory cytokines on the isolated human sebaceous infundibulum. J Invest Dermatol 1998;110:410-5.

[68] Cunliffe WJ, Holland DB, Clark SM, Stables GI. Comedogenesis: some new aetiological, clinical and therapeutic strategies. Br J Dermatol 2000;142: $1084-91$.

[69] Ingham E, Eady EA, Goodwin CE, Cove JH, Cunliffe WJ. Pro-inflammatory levels of interleukin-1 alpha-like bioactivity are present in the majority of open comedones in acne vulgaris. J Invest Dermatol 1992:98:895-901.

[70] Szabó K, Tax G, Kis K, Szegedi K, Teodorescu-Brinzeu DG, Diószegi C, et al. Interleukin- $1 \mathrm{~A}+4845(\mathrm{G}>\mathrm{T})$ polymorphism is a factor predisposing to acne vulgaris. Tissue Antigens 2010;76:411-5.

[71] Kobayashi Y, Yamamoto K, Saido T, Kawasaki H, Oppenheim JJ, Matsushima K. Identification of calcium-activated neutral protease as a processing enzyme of human interleukin 1alpha. Proc Natl Acad Sci U S A 1990;87:5548-52.

[72] Mosley B, Urdal DL, Prickett KS, Larsen A, Cosman D, Conlon PJ, et al. The interleukin-1 receptor binds the human interleukin-1 alpha precursor but not the interleukin-1 beta precursor. J Biol Chem 1987;262:2941-4.

[73] Lee S, Temple S, Roberts S, Price P. Complex effects of IL1A polymorphism and calpain inhibitors on interleukin 1 alpha (IL-1 alpha) mRNA levels and secretion of IL-1 alpha protein. Tissue Antigens 2008;72:67-71.

[74] Kawaguchi Y, Tochimoto A, Hara M, Kawamoto M, Sugiura T, Saito S, et al Contribution of single nucleotide polymorphisms of the IL1A gene to the cleavage of precursor IL-1alpha and its transcription activity. Immunogenetics 2007:59:441-8

[75] Zouboulis CC, Chen WC, Thornton MJ, Qin K, Rosenfield R. Sexual hormones in human skin. Horm Metab Res 2007;39:85-95.

[76] George R, Clarke S, Thiboutot D. Hormonal therapy for acne. Semin Cutan Med Surg 2008;27:188-96

[77] Kurokawa I, Danby FW, Ju Q, Wang X, Xiang LF, Xia L, et al. New developments in our understanding of acne pathogenesis and treatment. Exp Dermatol 2009; 18:821-32.

[78] Randall VA. Androgens and hair growth. Dermatol Ther 2008;21:314-28. 
[79] Choong CS, Wilson EM. Trinucleotide repeats in the human androgen receptor: a molecular basis for disease. J Mol Endocrinol 1998;21:235-57.

[80] Stanford JL, Just JJ, Gibbs M, Wicklund KG, Neal CL, Blumenstein BA, et al. Polymorphic repeats in the androgen receptor gene: molecular markers of prostate cancer risk. Cancer Res 1997;57:1194-8.

[81] Yang Z, Yu H, Cheng B, Tang W, Dong Y, Xiao C, et al. Relationship between the CAG repeat polymorphism in the androgen receptor gene and acne in the Han ethnic group. Dermatology (Basel) 2009;218:302-6.

[82] Pang Y, He CD, Liu Y, Wang KB, Xiao T, Wang YK, et al. Combination of short CAG and GGN repeats in the androgen receptor gene is associated with acne risk in North East China. J Eur Acad Dermatol Venereol 2008;22:1445-51.

[83] Roberts ES, Vaz AD, Coon MJ. Role of isozymes of rabbit microsomal cytochrome P-450 in the metabolism of retinoic acid, retinol, and retinal. Mol Pharmacol 1992;41:427-33.

[84] Zouboulis CC, Korge B, Akamatsu H, Xia LQ, Schiller S, Gollnick H, et al. Effects of 13-cis-retinoic acid, all-trans-retinoic acid, and acitretin on the proliferation, lipid synthesis and keratin expression of cultured human sebocytes in vitro. J Invest Dermatol 1991;96:792-7.

[85] Zouboulis CC, Korge BP, Mischke D, Orfanos CE. Altered proliferation, synthetic activity, and differentiation of cultured human sebocytes in the absence of vitamin A and their modulation by synthetic retinoids. J Invest Dermatol 1993;101:628-33.

[86] Kawajiri K, Watanabe J, Gotoh O, Tagashira Y, Sogawa K, Fujii-Kuriyama Y. Structure and drug inducibility of the human cytochrome P-450c gene. Eur J Biochem 1986;159:219-25.

[87] Crofts F, Taioli E, Trachman J, Cosma GN, Currie D, Toniolo P, et al. Functional significance of different human CYP1A1 genotypes. Carcinogenesis 1994;15: 2961-3.

[88] Miller WL. Early steps in androgen biosynthesis: from cholesterol to DHEA. Baillieres Clin Endocrinol Metab 1998;12:67-81.
[89] Carey AH, Waterworth D, Patel K, White D, Little J, Novelli P, et al. Polycystic ovaries and premature male pattern baldness are associated with one allele of the steroid metabolism gene CYP17. Hum Mol Genet 1994;3:1873-6.

[90] Bugano DD, Conforti-Froes N, Yamaguchi NH, Baracat EC. Genetic polymorphisms, the metabolism of estrogens and breast cancer: a review. Eur J Gynaecol Oncol 2008;29:313-20.

[91] Price DK, Franks ME, Figg WD. Genetic variations in the vitamin D receptor androgen receptor and enzymes that regulate androgen metabolism. J Urol 2004;171:S45-9.

[92] He L, Yang Z, Yu H, Cheng B, Tang W, Dong Y, et al. The relationship between CYP17 -34T/C polymorphism and acne in Chinese subjects revealed by sequencing. Dermatology (Basel) 2006;212:338-42.

[93] Nedelcheva KV, Haraldsen EK, Anderson KB, Lonning PE, Erikstein B, et al. CYP17 and breast cancer risk: the polymorphism in the 5' flanking area of the gene does not influence binding to Sp-1. Cancer Res 1999;59:2825-8.

[94] Melnik BC. Role of FGFR2-signaling in the pathogenesis of acne. Dermatoendocrinology 2009;1:141-56.

[95] Munro CS, Wilkie AO. Epidermal mosaicism producing localised acne: somatic mutation in FGFR2. Lancet 1998;352:704-5.

[96] Melnik BC, Vakilzadeh F, Aslanidis C, Schmitz G. Unilateral segmental acneiform naevus: a model disorder towards understanding fibroblast growth factor receptor 2 function in acne? Br J Dermatol 2008;158:1397-9.

[97] Berra B, Rizzo AM. Glycemic index, glycemic load: new evidence for a link with acne. J Am Coll Nutr 2009;28;suppl:450S-4S.

[98] Melnik BC. Acneigenic stimuli converge in phosphoinositol-3 kinase/Akt/ FoxO1 signal transduction. Clin Exp Dermatol 2010;1:101.

[99] López-Jaramillo P, Silva SY, Rodríguez-Salamanca N, Duràn A, Mosquera W, Castillo V. Are nutrition-induced epigenetic changes the link between socioeconomic pathology and cardiovascular diseases? Am J Ther 2008;15: 362-72. 